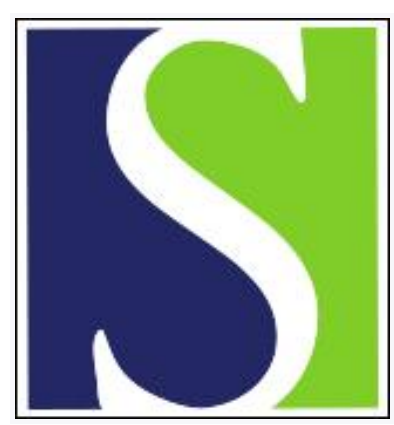

Scand J Work Environ Health 1997;23(1):37-40

https://doi.org/10.5271/sjweh.176

Issue date: Feb 1997

Elevated serum levels of pantropic p53 proteins in chromium workers

by Hanaoka T, Yamano Y, Katsuno N, Kagawa J, Ishizu S

Key terms: biomarkers; environmental carcinogenesis; molecular epidemiology; risk assessment

This article in PubMed: www.ncbi.nlm.nih.gov/pubmed/9098910

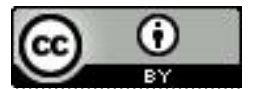




\title{
Elevated serum levels of pantropic p53 proteins in chromium workers
}

\author{
by Tomoyuki Hanaoka, MD, ${ }^{1}$ Yuko Yamano, PhD, ${ }^{2}$ Naochika Katsuno, MD, ${ }^{1}$ Jun Kagawa, MD, ${ }^{2}$ \\ Sumiko Ishizu, $M D^{\prime}$
}

\begin{abstract}
Hanaoka T, Yamano $Y$, Katsuno $N$, Kagawa J, Ishizu S. Elevated serum levels of pantropic p53 proteins in chromium workers. Scand J Work Environ Health 1997;23(1):37-40.
\end{abstract}

\begin{abstract}
Objectives This study investigated the possibility of applying serum pantropic p53 proteins in molecular epidemiologic studies, as a biomarker of environmental carcinogenesis. The serum levels of pantropic p53 proteins were determined in workers with past exposure to hexavalent chromium compounds.

Methods Thirty-one male workers occupationally exposed to hexavalent chromium compounds in the production of chromium compounds for 0 to 23 years served as the exposed group. The referents were 10 volunteers without work-related exposure to chemicals. In the determination of pantropic p53 proteins, commercially available kits for enzyme-linked immunosorbent assay were used which quantitatively detected both mutant and wild-type human 553 proteins.

Results The serum level of pantropic p53 proteins was in the range of 116.4 to $1122.6 \mathrm{pg} / \mathrm{ml}$ for the exposed workers and of 117.4 to $305.8 \mathrm{pg} / \mathrm{ml}$ for the referents. Nineteen percent of the exposed workers had a high p53 protein level ( 6 out of 31 ) when compared with the referents. All but 1 of the 6 workers had been occupationally exposed to chromium compounds for more than 11 years. Two of the 3 workers with a past history of lung cancer also showed high levels.
\end{abstract}

Conclusions Our findings confirm that the application of p53 proteins as a biomarker of environmental carcinogenesis merits further exploration.

Key terms biomarkers, environmental carcinogenesis, molecular epidemiology, risk assessment.

Mutations of tumor suppressor genes are considered to play important roles in the process of multistage carcinogenesis $(1-4)$. The p53 gene is a well-known tumor suppressor which encodes a $53 \mathrm{kD}$ nuclear phosphoprotein (5). The potential roles of the normal product of the p53 gene, the wild-type p53 protein, are considered to be a regulator of cell division $(6-8)$, a controller of transcriptional activation $(7,9)$, and a marker of DNA (deoxyribonucleic acid) damage $(10,11)$. When point mutations occur in the p53 gene, the mutated gene produces mutant p53 proteins that lose the normal functions of the wild-type of $\mathrm{p} 53$ protein and express characteristics of an activated oncogene product (12).

Mutations of the p53 gene have been found in several types of cancers, including cancer of the lung (13-16). Moreover, immunohistochemical studies have detected p53 proteins in several human malignancies, including lung cancer (17). Recently, the p53 proteins have also been detected in the serum of lung cancer patients (18, 19). These studies suggested the possible application of p53 proteins in the assessment of carcinogenesis and the development of cancer.

In this study, we determined the serum levels of pantropic p53 proteins in workers with past exposure to hexavalent chromium compounds to investigate the possibility of applying serum pantropic $\mathrm{p} 53$ proteins in molecular epidemiologic studies as a biomarker of environmental carcinogenesis. This group of workers was used because they have been recognized as being at high risk for lung cancer and other respiratory malignancies (20).

\section{Subjects and methods}

The subjects were 31 male workers with past occupational exposure to hexavalent chromium compounds. They had all worked in a chromate plant that produced sodium and potassium bichromate, chromic anhydride, and other compounds from ores. According to published

1 Division of Work Environment and Occupational Health, Institute for Science of Labour, Kawasaki, Japan.

2 Department of Hygiene and Public Health, Tokyo Women's Medical College, Tokyo, Japan.

Reprint requests to: Dr Tomoyuki Hanaoka, Division of Work Environment and Occupational Health, Institute for Science of Labour, 2-8-14 Sugao Miyamae-ku, Kawasaki 216, Japan. 
results on the chromate exposure in the same plant during a period similar to that when the subjects had worked there, the concentration of chromate dust in the work area was estimated to be $1.19-210.10 \mathrm{mg} / \mathrm{m}^{3}$ and the concentration of chromate mist was $0.04-8.43 \mathrm{mg} / \mathrm{m}^{3}$ (21). However, the exposure had ceased approximately 20 years prior to this study. The average age of the exposed groups was 54.8 (43-63 range) years. There were 14 smokers, 6 past smokers, and 11 nonsmokers. The duration of exposure ranged from 0 to 23 years. The workers whose past exposure was 0 years had no record of chromate exposure even though they had been involved in equipment repair, boiler operation, and other such activities with exposure similar to that of other workers who had worked in the production process.

The health status of each subject was confirmed in a general physical examination. Three workers had a history of lung cancer diagnosed by bronchoscopic examination. The pathological type of malignant tissue was squamous cell carcinoma in these 3 , all of whom had undergone operative resection. The intervals between surgery and blood sampling were 5, 11, and 17 years. None of the others had any serious clinical disorders except for 1 case of Behçet disease.

As referents, 10 volunteers were selected according to age, the average age being 54.3 (45-59 range) years. None of them had any occupational chemical exposure, nor were there any clinically significant diseases. The subjects consisted of 5 smokers, 3 past smokers, and 2 nonsmokers.

All the participants in this study gave their informed consent.

After sampling peripheral venous blood, we immediately collected serum. The serum samples were stored at $-80^{\circ} \mathrm{C}$ until the analysis.

For the detection of pantropic p53 proteins, we used the Pantropic p53 Quantitative ELISA Assay ${ }^{\mathrm{TM}}$ (Oncogene Science Inc, California, United States). This assay

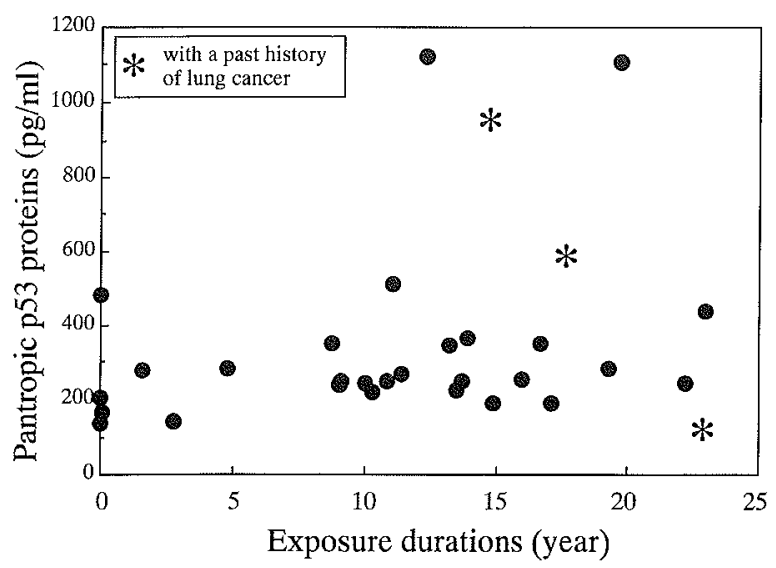

Figure 1. Correlation between the serum pantropic p53 protein levels and exposure durations of the chromium workers. is a sandwich enzyme immunoassay which quantitatively detects both mutant and wild-type human p53 proteins. The detection system consisted of mouse monoclonal antibody specific for human p53 proteins (PAb1801), rabbit p53 polyclonal antibodies, horseradish peroxidase conjugated to goat antirabbit immunoglobulin $\mathrm{G}$, and chromogenic substrate $o$-phenylenediamine. The colored reaction products were measured at 490/630 nm using a microplate reader (MR5000, Dynatech Laboratories, Inc, Virginia, United States).

All the samples were tested both "blind" and by duplicate analysis.

\section{Results}

The mean serum level of pantropic p53 proteins was 355.7 (SD 259.5, range 116.4-1122.6) $\mathrm{pg} / \mathrm{ml}$ for the exposed workers and 217.1 (SD 58.0, range 117.4 $305.8) \mathrm{pg} / \mathrm{ml}$ for the referents.

Figure 1 shows the correlation between the serum levels of pantropic p53 proteins and the exposure duration of the workers. No significant difference was detected for the mean levels between the workers and the referents. However, some of the exposed subjects had high levels. Compared with the referents, $36 \%$ (11 out of 31) of the exposed workers had a p53 protein value that was over the mean $+2 \mathrm{SD}(333.2 \mathrm{pg} / \mathrm{ml})$. Nineteen percent ( 6 of 31 ) of the exposed workers had a p53 protein value that was over the mean +4 SD (449.2 pg/ml), 2 with levels exceeding $1000 \mathrm{pg} / \mathrm{ml}$. All but 1 of the 6 had been occupationally exposed to chromium compounds for more than 11 years. The 1 exception had no record of exposure. However, he had also been exposed to chromium compounds as described in the Subjects and Methods section. Two of the 3 workers with a past history of lung cancer had values in this high range, the interval since surgery being 5 years for one and 11 years for the other. The worker for whom the interval was 17 years had a relatively low level.

No significant differences in the serum p53 protein levels were observed for the smokers, past smokers, and nonsmokers among either the exposed workers or the referents in an analysis of variance. Neither was there any significant correlation between the serum p53 protein levels and the Brinkman index.

\section{Discussion}

In this study, we observed 6 workers with high levels of serum pantropic 553 proteins, as compared with the average reference level. In a fundamental study, using the 
same analytical method, the levels of these proteins were in the 197.8-536.3 (mean 317.6, SD 79.8) pg/ml range for 39 healthy office workers. There were no detectable effects of age or smoking status on the protein level (unpublished observations). Compared with the results of the aforementioned study, the levels of 6 workers in this study exceeded the mean +2 SD level $(477.2 \mathrm{pg} / \mathrm{ml})$ of the healthy volunteers.

The biological significance of high levels of circulating 553 proteins has not been fully clarified. In a previous report, it was speculated that p53 protein may have been released into the patients' sera by necrotic tissue, and it was thus suggested that serum p53 proteins might serve as a useful diagnostic tool for evaluating invasive tumors (18). However, several pathological studies have detected p53 alterations in preneoplastic lesions of the lung and have suggested that p53 changes occur in the early stages of lung cancer development $(22,23)$. A recent report suggested that the overexpression of mutant p53 may be detectable in vivo via the identification of increased amounts of the protein in the sera of some persons exposed to environmental carcinogens before the detection of clinical disease (19).

Brandt-Rauf et al (24-26) have reported elevated levels of several oncoproteins in healthy workers with occupational exposure to numerous chemicals. They concluded that serum oncoproteins might be useful biomarkers for detecting the early effects of carcinogens in molecular epidemiologic studies. In our study, the workers who had had a long duration of exposure to hexavalent chromium compounds and who were thus presumed to be at high risk for lung cancer showed high levels of serum pantropic p53 proteins. If exposure duration actually reflects the degree of exposure (ie, an increased opportunity for gene damage), this finding would suggest that the level of circulating p53 proteins is an early effect-marker and thus is a possible indicator of cancer risk.

We speculate that circulating p53 proteins can increase in different ways. One possibility, assuming that continuous DNA damage results from chromium adhering to the lung, is that wild-type p53 protein is produced in nuclei; it then leaves the cells and enters the circulation. Increased p53 protein has been shown to be produced as an agent resistant to DNA damage (10-11). Another possibility is that the p53 gene itself can be damaged by chromium compounds or other suspected intermediates, such as superoxide radicals, and thereby produce abnormal amounts of wild-type p53 protein or increased mutant p53 protein. The analysis of mutant p53 proteins holds the key to solving this problem. In our preliminary study, no elevation was observed in either the exposed workers or the referents. Further studies are needed in which mutant $p 53$ proteins are analyzed with methods yielding reproducible results.
Molecular biomarkers are expected to be useful for the assessment of individual risk due to environmental carcinogen exposure (27). From the aspect of occupational and environmental health, genetic monitoring using molecular biomarkers is considered to be a promising strategy for identifying hazards and indicating actions which should be taken to reduce the hazardous exposure (28). Increased serum p53 proteins cannot explain the entire cancer risk because the level is occasionally within the normal range even in cancer patients. However, our findings confirm the potential use of serum pantropic p53 proteins as a biomarker of environmental carcinogenesis.

\section{Acknowledgments}

We are grateful to all the volunteers who participated in this study. This work was supported in part by a grant-inaid for scientific research from the Ministry of Education, Science, Culture and Sports, Japan.

\section{References}

1. Vogelstein B, Fearon ER, Hamilton SR, Kern SE, Preisinger AC, Leppert $\mathrm{M}$, et al. Genetic alterations during colorectaltumour development. N Engl J Med 1988;319:525-32.

2. Spandidos DA, Anderson MLM. Oncogenes and oncosuppressor genes. J Pathol 1989;157:1-10.

3. Fearon F, Vogelstein B. A genetic model for colorectal tumorogenesis. Cell 1990;61:759-67.

4. Stein WD. Analysis of cancer incidence data on the basis of multistage and clonal growth models. Adv Cancer Res 1991; $56: 161-213$.

5. Lane DP, Crawford LV. T antigen is bound to a host protein in SV40-transformed cells. Nature 1979;278:261-3.

6. Finlay CA, Hinds PW, Levine AJ. The p53 proto-oncogene can act as a suppressor of transformation. Cell 1989;57:108393

7. Shay JW, Werbin H, Funk WD, Wright WE. Cellular and molecular advances in elucidating 553 function. Mutat Res 1992;277:163-71.

8. Ullrich SJ, Andersin CW, Mercer WE, Appella E. The p53 tumor suppressor protein, a modulator of cell proliferation. $\mathrm{J}$ Biol Chem 1992;267:15259-62.

9. Yew PR, Berk AJ. Inhibition of p53 transactivation required for transformation by adenovirus early 1B protein. Nature 1992:357:82-5.

10. Lane DP. p53, guardian of the genome. Nature 1992;358:156.

11. Lu X, Park SH, Thompson TC, Lane DP. Ras-induced hyperplasia occurs with mutation of $\mathrm{p} 53$, but activated ras and myc together can induce carcinoma without p53 mutation. Cell 1992;70:153-61.

12. Lane DP, Benchimol S. p53: oncogene or anti-oncogene? Genes Dev 1990:4:1—8.

13. Chiba I, Takahashi T, Nau MM, D'Amico D, Curiel DT, 
Mitsudomi T, et al. Mutations in the 553 gene are frequent in primary resected, non-small cell lung cancer. Oncogene 1990; 5:1603-10.

14. Hollstein M, Sidransky D, Vogelstein B, Harris CC. p53 mutations in human cancers. Science 1991;253:49- 53.

15. Miller CW, Simon K, Aslo A, Kok K, Yokota J, Buys CHCM, et al. p53 mutations in human lung tumours. Cancer Res 1992; 52:1695-8.

16. Suzuki H, Takahashi T, Kuroishi T, Suyama M, Ariyoshi $Y$, Takahashi $T$, et al. p53 mutations in non-small cell lung cancer in Japan: association between mutations and smoking. Cancer Res 1992;52:734-6.

17. Papadakis E, Malliri A, Linardopoulos S, Karaiossifidi H, Field JK, Spandidos DA. Ras and p53 expression in non-small cell lung cancer patients: p53 over-expression correlates with a poor prognosis. Int J Oncol 1992;1:403-13.

18. Fontanini G, Foire L, Bigini D, Visnati S, Calvo S, Mussi A, et al. Levels of p53 antigen in the serum of non-small cell lung cancer patients correlate with positive p 53 immunohistochemistry on tumor sections, tumor necrosis and nodal involvement. Int J Oncol 1994;5:553-8.

19. Partanen R, Koskinen H, Oksa P, Hemminki K, Carney W, Smith $S$, et al. Serum oncoproteins in asbestosis patients. Clin Chem 1995;41:1844--7.

20. International Agency For Research on Cancer (IARC). Nickel and welding. Lyon: IARC, 1990. IARC monographs on the evaluation of carcinogenic risk to humans, vol 49.

21. Suzuki T, Ishikawa K, Hirokawa T, Minagawa Y, Ichimori W.
A hygienic survey of a chromate-producing plant. Bull Inst Public Health 1959;8:39-50.

22. Sozzi G, Miozza M, Donghi R, Pilotti S, Cariani CT, Pastorino $U$, et al. Deletions of $17 \mathrm{p}$ and $\mathrm{p} 53$ mutations in preneoplastic lesions of the lung. Cancer Res 1992;52:6079-82.

23. Sundaresan V, Ganly P, Hasleton P, Rudd R, Sinha G, Bleehen NM, et al. p53 and chromosome 3 abnormalities, characteristic of malignant lung tumours are detectable in preinvasive lesions of the bronchus. Oncogene 1992;7:1989-97.

24. Brandt-Rauf PW, Niman HL. Serum screening for oncogene proteins in workers exposed to PCBs. Br J Ind Med 1988;45: 689-93.

25. Brandt-Rauf PW, Smith SJ, Niman HL, Goldstein MD, Favata E. Serum oncogene proteins in hazardous waste workers. J Soc Occup Med 1989;39:141-3.

26. Brandt-Rauf PW, Smith S, Niman HL, Yohannan W, Hemminki K, Perera FP, et al. Serum oncogene proteins in foundry workers. J Soc Occup Med 1990;40:11-14.

27. Hemminki K. Use of chemical, biological, and genetic markers in cancer epidemiology and risk assessment. Am J Ind Med 1992;21:65-76.

28. Damme KV, Casteleyn L, Heseltine E, Huici A, Sorsa M, van Larebeke N, et al. Individual susceptibility and prevention of occupational diseases: scientific and ethical issues. J Occup Environ Med 1995;37:91—9.

Received for publication: 14 May 1996 